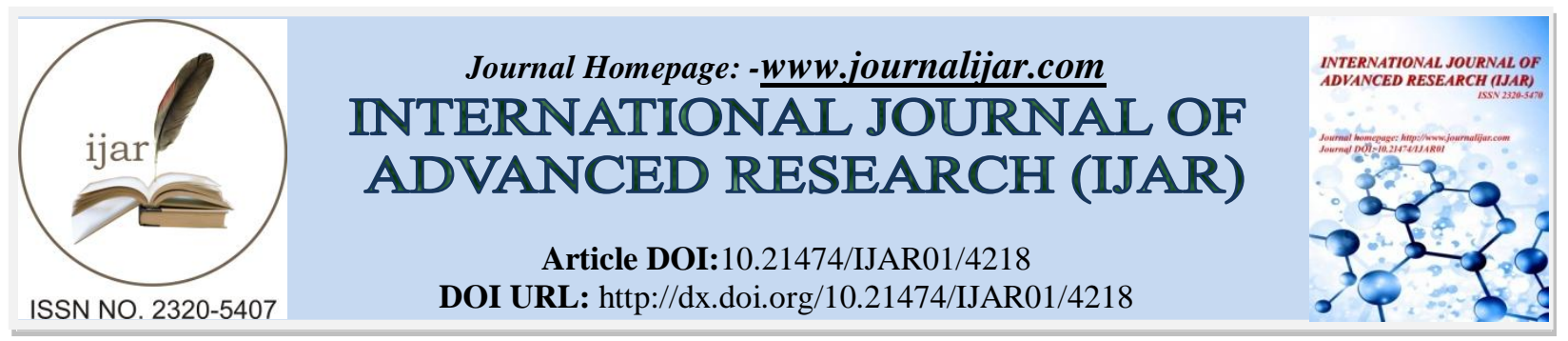

RESEARCH ARTICLE

\title{
BIOLOGICAL EFFICACY OF THREE ESSENTIAL OILS AND AZADIRACHTA INDICA VEGETABLE OIL IN THE CONTROL OF AN INSECT PEST OF COWPEA GRAIN: CALLOSOBRUCHUS MACULATUS (COLEOPTERA: BRUCHIDAE).
}

\author{
"Kpatinvoh Brice ${ }^{1}$, Zannou Elisabeth ${ }^{2}$ and Dahouénon-Ahoussi Edwige'. \\ 1. Laboratory of Study and Research in Applied Chemistry, Polytechnic School of Abomey-Calavi, University of \\ Abomey-Calavi, 01 BP: 2009 Cotonou, (Benin). \\ 2. Laboratory of Agricultural Entomology (LEAg), School of Sciences and Techniques of Vegetal Production, \\ University of Abomey-Calavi, 01 BP: 2009 Cotonou, (Benin).
}

\section{Manuscript Info}

Manuscript History

Received: 17 March 2017

Final Accepted: 20 April 2017

Published: May 2017

Key words:-

cowpea, efficacy, essential oils, insecticide, repellent.

\section{Abstract}

Background : Several methods are recommended for the control of cowpea pests. These include biological control, chemical control, resistance of the host plant and cultural practices. Thus, the present study aims to assess the biological effectiveness of three essential oils and zadirachta. indica oil in the control of an insect pest of cowpea grain: Callosobruchus maculatus.

Methods: The biological efficacy of essential oils of Eucalyptus camaldulensis, Cymbopogon citratus, Cymbopogon nardus and vegetable oil of Azadirachta indica was evaluated on Callosobruchus maculatus adults in cowpea under laboratory conditions.

Result: The results revealed that the essential oils as well as the $A$. indica vegetable oil tested had significant insecticidal and repellent activities on the adults of $C$. maculatus when the dose and exposure time increased from 0 to $20 \mu \mathrm{l} / \mathrm{l}$ of air for $6 \mathrm{~h}$ and 0 to $2000 \mu \mathrm{l} / \mathrm{l}$ of air for $96 \mathrm{~h}$, respectively.

Conclusion: The four plants tested had good biological activity with respect to the cowpea beetle $C$. maculatus.

Copy Right, IJAR, 2016,. All rights reserved.

\section{Introduction:-}

In order to cope with the increasing demand food of country's populations, it is necessary to increase agricultural production by increasing yields or cultivable areas and reducing losses before and after harvest (Delobel and Tran, 1993).

Indeed, in the tropics, cowpea is the source of the cheapest proteins that can substitute meat (Rahman and al., 2008). It thus represents a significant source of income for many agricultural households in sub-Saharan Africa. Despite its importance, insect pests cause the greatest problem in cowpea (Bottenberg and al., 1997). Consequently, postharvest conservation remains one of the key factors for food security in tropical countries. In Africa in general and particularly in Benin, agricultural production is seasonal, while the needs of consumers extend throughout the year. There is a need for an adequate phytosanitary policy to spare populations from the risk of food shortages during the off-season. In this perspective, efforts have been made to develop new compounds to be substituted for those commonly used. The use of renewable raw materials of plant origin for the manufacture of bioinsecticides 
corresponds to the need to respond to current environmental realities such as the fight against the greenhouse effect, reduction of pollution, a low toxicological effect and biodegradation Of the product (Hernandez Ochoa, 2005). Research has focused on biocidal natural products extracted from many plants.

The present study aims to evaluate the insecticidal and insect repellent activities of Cymbopogon citratus, Eucalyptus camaldulensis, Cymbopogon nardus essential oils and A. indica vegetable oil on C. maculatus, principal pest of cowpea in storage. This study attempts to evaluate the efficacy of three essential oils as well as A. indica vegetable oil by contact, inhalation and repulsivity on the $C$. maculatus population.

\section{Material and Method:- \\ Equipment:- \\ Plant Material:- \\ Plant species:-}

Four plant species were used in this study to evaluate the efficacy of cowpea pests in culture. These include Cymbopogon citratus, Cymbopogon nardus, Eucalyptus camaldulensis and Azadirachta indica. The four plants are well known in African pharmacopoeia.

\section{Cowpea:-}

The cowpea variety used is "Tola" and comes from the "Dantokpa" market and the "Ouando" market. Cowpea seeds are sorted and stored at $-20^{\circ} \mathrm{C}$ for freezing for two weeks. This operation resulted in the removal of any trace of an earlier seed infestation.

Before the tests, these seeds came out of freezing and exposed on bench under shelter for two hours of time.

\section{Animal Equipment:-}

The animal material was the adults beetle of Callossobruchus maculatus, a very cosmopolitan species that is considered as best injurious for cowpea stock (Giga and Smith, 1983). This beetle presents two morphological forms under conditions of overpopulation of the breeding substrate. It is the sailboat (able of flying and presenting a reproductive quiescence at the beginning of the imaginary life) and the non-sailor form (unable to fly and sexually active as soon as seeds emerge). For our experiments, we used adults of the non-sailor form raised in the entomology laboratory of the Faculty of Agronomic Sciences of the University of Abomey-Calavi.

\section{Method:-}

Extraction of essential oils and $A$. indica oil:-

The method of extraction of the various essential oils of C. citratus, C. nardus and E. camaldulensis used in this study is steam distillation. Similarly, the method of vegetable oil of A. indica extracting was performed by cold pressing.

\section{Contact Treatment:-}

Ten pairs of adult beehives (aged 0-24h) were introduced into glass petri dishes containing $50 \mathrm{~g}$ of Vigna unguiculata seeds previously treated with each of the three essential oils and A. indica vegetable oil at different doses $(1,2,5,10$ and $20 \mu \mathrm{l} / 50 \mathrm{~g})$. The latter were placed in a controlled oven $\left(30 \pm 1^{\circ} \mathrm{C}\right.$ and $70 \pm 5 \%$ relative humidity).

The insecticidal activity was evaluated by carrying out five replicates for each dose as well as for the control batches (without treatment). Some biological parameters of the beetle as life expectancy (longevity), number of eggs laid (fertility), egg hatching rate and viability rate (larval mortality) were evaluated.

Dead individuals were counted in each box every one (01) hour from the beginning of the trial until the death of all adults.

The count of eggs laid (hatched and unhatched eggs) on the seeds is carried out from the fifteenth day of the beginning of the test, under a binocular magnifying glass ( $\mathrm{G} \times 40)$.

The viable hatching eggs are recognized either by the presence of the larva visible through the chorion or by their white opaque appearance due to the accumulation of a white powder resulting from the activity of the neonate larva which digs its gallery in The seed (Kellouche and al., 2004). The count of first generation offspring was taken from 
the 25th to the 45th day of the start of treatment. Thus, adult individuals are removed from the boxes as they emerge from the treated seeds.

\section{Lifetime inhalation test (longevity) of $\boldsymbol{C}$. maculatus adults:-}

This test consists of studying the effect of each of the four plants on the adult mortality rate of $C$. maculatus by inhalation.

In glass jars of one liter volume, a dose of essential oils or vegetable oil is placed on cotton suspended with a thread on the face of the lid. Ten pairs of $C$. maculatus ages from 0 to $24 \mathrm{~h}$ were introduced into each jar which is hermetically sealed. For each test, five replicates were performed for each dose $(1 ; 2 ; 5 ; 10$ and $20 \mu \mathrm{l})$ and each exposure time $(6,12,18,24,48,72$ and 96 hours) in parallel a control was carried out (cotton without plant extracts). Dead individuals were removed from the jars and put in petri dishes for 24 hours. We observe under a binocular magnifying glass at magnification 40 for the count of dead beetle

Mortality is calculated and corrected by the Abbott formula (1925).

\section{Repellent test of adults of $C$. maculatus:-}

Disks of filter paper were cut into two equal parts. One of the half disks is treated with a dose $(1 ; 2 ; 5 ; 10$ and $20 \mu \mathrm{l})$ of essential oils and vegetable oil diluted in $1 \mathrm{ml}$ of solvent (ethanol for essential oils and hexane for vegetable oil ), The other part was sprayed with the solvent only.

The dish thus prepared was left in the open air for 15 minutes for complete evaporation of the solvent. The two filter paper disks were joined together with an adhesive tape and deposited on the bottom of the Petri dishes. 10 pairs of C. maculatus, aged less than $24 \mathrm{~h}$, are deposited on the junction of the two papers.

After one hour, a count of the bruises present on each of the two parts is carried out. The percentage of repulsivity (PR), induced by plant extracts on adult beetles, is calculated according to the formula of Mc Donald and al. (1970).

The average repulsion percentage for each oil is calculated and attributed to one of the different repulsive classes, according to Mc Donald and $a$ l. (1970).

\section{Statistical Analysis of Data:- ANOVA Test:-}

The results of the various trials were subjected to the ANOVA according to several classification criteria followed by the 5\% Newman and Keuls test, using Statbox version 5 software, when there is a Significant difference between the different treatments

\section{Calculation of $\mathrm{LD}_{50}$ and $\mathrm{LD}_{90:-}$}

The efficacy of a toxic substance is measured by its $\mathrm{LD}_{50}$ and $\mathrm{LD}_{90}$, which respectively determine the amount of toxic substance causing death $50 \%$ and $90 \%$ of the individuals in the treated population. They are determined from the plot of the regression lines. The number of individuals killed in a toxic-treated population is not the actual number killed by this substance. There is a natural mortality in any population that adds to the mortality caused by the applied substance. Percentages of mortality should be corrected by the Abbott formula

\section{Results and Discussions:-}

The results obtained show a significant variation in the bioactivity of the essential oil and A. indica vegetable oil tested by contact, by fumigation and by repulsivity in the same way as $C$. maculatus.

\section{Contact Test:-}

\section{Effects on adult longevity:-}

The most important insecticidal effects were recorded in treatments with essential oils of E.camaldulensis, $C$. citratus and $C$. nardus. Indeed, the lifetime of the adults of $C$. maculatus is between $6 \mathrm{~h}$ and $20 \mathrm{~h}$, for the various extracts tested at the dose $20 \mu \mathrm{l}$; The beetles of the control batches lived about 7 days $(172 \pm 3.09 \mathrm{~h})$ (Table 1). Analysis of the variance revealed a significant difference for the essential oil and $A$. indica vegetable oil $(\mathrm{P}=0.000$ $<0.05$ ) 
Table 1:- Mean longevity (h) of $C$. maculatus adults treated with essential oil and A. indica vegetable oil (mean \pm $\mathrm{SD}$ ) at different doses (The averages that do not share a letter are different, according to the Newman and Keuls test at the $\mathrm{P}=5 \%$ threshold).

\begin{tabular}{|c|c|c|c|c|}
\hline Dose $(\mu \mathrm{l})$ & C. citratus & C. nardus & E. camaldulensis & A. indica \\
\hline 0 & $\begin{array}{c}172.00 \pm 3.10 \\
\text { (a) }\end{array}$ & $\begin{array}{c}172.00 \pm 3.10 \\
\text { (a) }\end{array}$ & $\begin{array}{c}172.00 \pm 3.10 \\
\text { (a) }\end{array}$ & $\begin{array}{c}172.00 \pm 3.10 \\
\text { (a) }\end{array}$ \\
\hline 1 & $\begin{array}{c}56.67 \pm 2.80 \\
(\mathrm{~d})\end{array}$ & $\begin{array}{c}64.83 \pm 5.16 \\
(\mathrm{c})\end{array}$ & $\begin{array}{c}25.00 \pm 2.45 \\
\text { (f) }\end{array}$ & $\begin{array}{c}91.83 \pm 4.26 \\
\text { (b) }\end{array}$ \\
\hline 2 & $46.83 \pm 3.82(\mathrm{e})$ & $56.67 \pm 5.16(\mathrm{~d})$ & $16.00 \pm 3.10(\mathrm{~g})$ & $66.67 \pm 5.61(\mathrm{c})$ \\
\hline 5 & $\begin{array}{c}23.00 \pm 2,45 \\
\text { (f) }\end{array}$ & $\begin{array}{c}29.00 \pm 4.52 \\
\text { (f) }\end{array}$ & $\begin{array}{l}6.00 \pm 0.00 \\
\text { (i) }\end{array}$ & $\begin{array}{c}57.67 \pm 3.39 \\
\text { (d) }\end{array}$ \\
\hline 10 & $\begin{array}{c}10.00 \pm 3.10 \\
\text { (j) }\end{array}$ & $\begin{array}{c}12.00 \pm 0.00 \\
\text { (j) }\end{array}$ & $\begin{array}{l}6.00 \pm 0.00 \\
\text { (i) }\end{array}$ & $\begin{array}{c}47.33 \pm 4.67 \\
\text { (e) }\end{array}$ \\
\hline 20 & $\begin{array}{l}6.00 \pm 0.00 \\
\text { (i) }\end{array}$ & $\begin{array}{l}6.00 \pm 0.00 \\
\text { (i) }\end{array}$ & $\begin{array}{l}6.00 \pm 0.00 \\
\text { (i) }\end{array}$ & $\begin{array}{c}20.17 \pm 3.37 \\
\text { (f) }\end{array}$ \\
\hline
\end{tabular}

\section{Effects on fertility of Females:-}

The essential oils of E.camaldulensis, C. citratus and C. nardus completely inhibit the laying of C. maculatus, at 10 $\mu \mathrm{l} / \mathrm{l}$, that of $A$. indica oil is the least toxic (table 2). In the control batches, the average number of eggs laid by ten females was $752.67 \pm 28.09$.

Analysis of the variance revealed a significant difference for the essential oil and $A$. indica vegetable oil $(\mathrm{P}=0.000$ $<0)$

Table 2:- Mean fertility of 10 females of $C$. maculatus on $V$. unguiculata seeds treated with essential oil and $A$. indica vegetable oil tested (No-letter averages are different according to Newman and Keuls test at $\mathrm{P}=5 \%$ )

\begin{tabular}{|c|c|c|c|c|}
\hline Dose $(\mu \mathrm{l})$ & C. citratus & C. nardus & E. camaldulensis & A. indica \\
\hline 0 & $\begin{array}{c}752.67 \pm 28.09 \\
\text { (a) }\end{array}$ & $\begin{array}{c}752.67 \pm 28.09 \\
\text { (a) }\end{array}$ & $\begin{array}{c}752.67 \pm 28.09 \\
\text { (a) }\end{array}$ & $\begin{array}{c}752,67 \pm 28.09 \\
\text { (a) }\end{array}$ \\
\hline 1 & $\begin{array}{l}37.67 \pm 2.08 \\
\text { (f) }\end{array}$ & $\begin{array}{l}39.67 \pm 1.53 \\
\text { (f) }\end{array}$ & $\begin{array}{c}32.33 \pm 2.52 \\
(\mathrm{~g})\end{array}$ & $\begin{array}{c}676.00 \pm 29.46 \\
\text { (b) }\end{array}$ \\
\hline 2 & $\begin{array}{l}10.00 \pm 2.00 \\
\text { (i) }\end{array}$ & $\begin{array}{c}16.00 \pm 3.61 \\
\text { (h) }\end{array}$ & $\begin{array}{l}7.00 \pm 1.00 \\
\text { (i) }\end{array}$ & $\begin{array}{l}600.00 \pm 2.00 \\
\text { (c) }\end{array}$ \\
\hline 5 & $\begin{array}{c}1.67 \pm 0.58 \\
\text { (j) }\end{array}$ & $\begin{array}{c}2.00 \pm 1.00 \\
\text { (j) }\end{array}$ & $\begin{array}{c}1.33 \pm 0.58 \\
\text { (j) }\end{array}$ & $\begin{array}{c}399.67 \pm 10.60 \\
\text { (d) }\end{array}$ \\
\hline 10 & $\begin{array}{c}0.00 \pm 0.00 \\
(\mathrm{k})\end{array}$ & $\begin{array}{c}0.00 \pm 0.00 \\
(\mathrm{k})\end{array}$ & $\begin{array}{c}0.00 \pm 0.00 \\
(\mathrm{k})\end{array}$ & $\begin{array}{c}110.67 \pm 10.07 \\
\text { (e) }\end{array}$ \\
\hline 20 & $\begin{array}{c}0.00 \pm 0.00 \\
(\mathrm{k})\end{array}$ & $\begin{array}{c}0.00 \pm 0,00 \\
(\mathrm{k})\end{array}$ & $\begin{array}{c}0.00 \pm 0.00 \\
(\mathrm{k})\end{array}$ & $\begin{array}{c}27.00 \pm 2.64 \\
(\mathrm{~g})\end{array}$ \\
\hline
\end{tabular}

\section{Effects on embryonic viability of $C$. maculatus:-}

The results obtained show a significant reduction in hatching eggs in the treated batches. The most important effects were recorded with the essential oils of E.camaldulensis, C. citratus and C. nardus which totally inhibited the eggs laid on the treated seeds at a dose of $5 \mu \mathrm{l} / 1$. The A. indica oil is the least toxic. The mean number of eggs hatched in the lotteries was $660.67 \pm 11.01$.

Analysis of the variance revealed a significant difference for the essential oil and A. indica vegetable oil $(\mathrm{P}=0.000$ $<0.05)$

Table 3:- Number of hatched eggs of $C$. maculatus on $V$. unguiculata seeds treated with the essential oil and $A$. indica vegetable oil tested (No-letter averages are different, according to the Newman and Keuls test at the $\mathrm{P}=5 \%$ threshold).

\begin{tabular}{|c|c|c|c|c|}
\hline Dose $(\boldsymbol{\mu l})$ & C. citratus & C. nardus & E. camaldulensis & A. indica \\
\hline 0 & $660.67 \pm 11.01$ & $660.67 \pm 11.01$ & $660.67 \pm 11.01$ & $660.67 \pm 11.01$ \\
& (a) & (a) & (a) & (a) \\
\hline 1 & $6.33 \pm 1.15$ & $8.67 \pm 1.15$ & $3.00 \pm 1.00$ & $420.33 \pm 2.51$ \\
\hline
\end{tabular}




\begin{tabular}{|c|c|c|c|c|}
\hline & (f) & (f) & (g) & (b) \\
\hline 2 & $\begin{array}{c}1.00 \pm 1.00 \\
\text { (h) }\end{array}$ & $\begin{array}{c}3.33 \pm 1.52 \\
(\mathrm{~g})\end{array}$ & $\begin{array}{c}0.33 \pm 0.57 \\
\text { (h) }\end{array}$ & $\begin{array}{c}207.33 \pm 8.33 \\
\text { (c) }\end{array}$ \\
\hline 5 & $\begin{array}{l}0.00 \pm 0.00 \\
\text { (i) }\end{array}$ & $\begin{array}{l}0.00 \pm 0.00 \\
\text { (i) }\end{array}$ & $\begin{array}{l}0.00 \pm 0,00 \\
\text { (i) }\end{array}$ & $\begin{array}{c}100.00 \pm 4.00 \\
\text { (d) }\end{array}$ \\
\hline 10 & $\begin{array}{l}0.00 \pm 0.00 \\
\text { (i) }\end{array}$ & $\begin{array}{l}0.00 \pm 0.00 \\
\text { (i) }\end{array}$ & $\begin{array}{l}0.00 \pm 0.00 \\
\text { (i) }\end{array}$ & $\begin{array}{c}46.67 \pm 3.21 \\
\text { (e) }\end{array}$ \\
\hline 20 & $\begin{array}{l}0.00 \pm 0.00 \\
\text { (i) }\end{array}$ & $\begin{array}{l}0.00 \pm 0.00 \\
\text { (i) }\end{array}$ & $\begin{array}{l}0.00 \pm 0.00 \\
\text { (i) }\end{array}$ & $\begin{array}{c}10.33 \pm 2.52 \\
\text { (f) }\end{array}$ \\
\hline
\end{tabular}

Effects on post-embryonic viability of $C$. maculatus:-

No progeny were observed in batches treated with the essential oils of E.camaldulensis, C. citratus and C. nardus at a dose of $2 \mu \mathrm{l} / \mathrm{l}$, which is not the same with A. indica oil.

Analysis of the variance revealed a significant difference for the essential oil and $A$. indica vegetable oil $(\mathrm{P}=0.000$ $<0.05)$

Table 4:- Number of viable eggs hatched with $C$. maculatus in treatments with the essential oil and $A$. indica vegetable oil tested (No-letter averages are different according to Newman and Keuls test at $\mathrm{P}=5 \%$ ).

\begin{tabular}{|c|c|c|c|c|}
\hline Dose $(\mu \mathrm{l})$ & C. citratus & C. nardus & E. camaldulensis & A. indica \\
\hline 0 & $\begin{array}{l}631.00 \pm 9.64 \\
\text { (a) }\end{array}$ & $\begin{array}{l}631.00 \pm 9.64 \\
\text { (a) }\end{array}$ & $\begin{array}{c}631.00 \pm 9.64 \\
\text { (a) }\end{array}$ & $\begin{array}{c}631.00 \pm 9.64 \\
\text { (a) }\end{array}$ \\
\hline 1 & $\begin{array}{c}2.33 \pm 0.58 \\
\text { (f) }\end{array}$ & $\begin{array}{c}3.33 \pm 0.58 \\
\text { (f) }\end{array}$ & $\begin{array}{c}1.00 \pm 1.00 \\
\text { (f) }\end{array}$ & $\begin{array}{c}310.00 \pm 11.13 \\
\text { (b) }\end{array}$ \\
\hline 2 & $\begin{array}{c}0.00 \pm 0.00 \\
(\mathrm{~g})\end{array}$ & $\begin{array}{c}0.00 \pm 0.00 \\
(\mathrm{~g})\end{array}$ & $\begin{array}{c}0.00 \pm 0.00 \\
(\mathrm{~g})\end{array}$ & $\begin{array}{c}124.67 \pm 5.03 \\
\text { (c) }\end{array}$ \\
\hline 5 & $\begin{array}{c}0.00 \pm 0.00 \\
(\mathrm{~g})\end{array}$ & $\begin{array}{c}0.00 \pm 0.00 \\
(\mathrm{~g})\end{array}$ & $\begin{array}{c}0.00 \pm 0.00 \\
(\mathrm{~g})\end{array}$ & $\begin{array}{l}72.33 \pm 2.51 \\
\text { (d) }\end{array}$ \\
\hline 10 & $\begin{array}{c}0.00 \pm 0.00 \\
(\mathrm{~g})\end{array}$ & $\begin{array}{c}0.00 \pm 0.00 \\
(\mathrm{~g})\end{array}$ & $\begin{array}{c}0.00 \pm 0.00 \\
(\mathrm{~g})\end{array}$ & $\begin{array}{l}25.67 \pm 4.04 \\
\text { (e) }\end{array}$ \\
\hline 20 & $\begin{array}{c}0.00 \pm 0.00 \\
(\mathrm{~g})\end{array}$ & $\begin{array}{c}0,00 \pm 0,00 \\
(\mathrm{~g})\end{array}$ & $\begin{array}{c}0.00 \pm 0.00 \\
(\mathrm{~g})\end{array}$ & $\begin{array}{l}5.67 \pm 1.53 \\
\text { (f) }\end{array}$ \\
\hline
\end{tabular}

\section{Inhalation test:-}

The results of the analysis of the variance showed a significant effect for the essential oil and A. indica vegetable oil $(\mathrm{P}=0.000<0.05)$. The essential oils of E.camaldulensis, $C$. citratus and $C$. nardus were found to be the most toxic after $12 \mathrm{~h}$ of exposure to the $10 \mu \mathrm{l} / 1$ of air dose, adult mortality of C. maculatus reached $85 \% 75 \%$ and $72 \%$, respectively (Table 5)

Table 5:- Mortality rate (\%) of adults of $C$. maculatus (inhalation test) with the essential oil and $A$. indica vegetable oil.

\begin{tabular}{|l|c|c|c|c|c|c|c|c|}
\hline Plant extracts & Dose $(\boldsymbol{\mu l})$ & \multicolumn{9}{|c|}{ Exposure Time (h) } \\
\cline { 2 - 8 } & & 6 & 12 & 18 & 24 & 48 & 72 & 96 \\
\hline \multirow{5}{*}{ C. citratus } & 0 & 0 & 0 & 0 & 0 & 0 & 0 & 0 \\
& 1 & 30 & 45 & 55 & 100 & - & - & - \\
& 2 & 35 & 62 & 65 & 100 & - & - & - \\
& 5 & 42 & 75 & 82 & 100 & - & - & - \\
& 10 & 65 & 100 & 100 & - & - & - & - \\
& 20 & 100 & - & - & - & - & - & - \\
\hline \multirow{5}{*}{ C. nardus } & 0 & 0 & 0 & 0 & 0 & 0 & 0 & 0 \\
& 1 & 25 & 40 & 50 & 100 & - & - & - \\
& 2 & 32 & 60 & 62 & 100 & - & - & - \\
& 5 & 40 & 72 & 80 & 100 & - & - & - \\
& 10 & 60 & 100 & - & - & - & - & - \\
& 20 & 100 & - & - & - & - & - & - \\
\hline
\end{tabular}




\begin{tabular}{|c|c|c|c|c|c|c|c|c|}
\hline \multirow{3}{*}{ E. camaldulensis } & 1 & 40 & 50 & 57 & 100 & - & - & - \\
& 2 & 46 & 65 & 70 & 100 & - & - & - \\
& 5 & 55 & 85 & 95 & 100 & - & - & - \\
& 10 & 72 & 100 & 100 & - & - & - & - \\
& 20 & 100 & - & - & - & - & - & - \\
\hline \multirow{5}{*}{ A. indica } & 0 & 0 & 0 & 0 & 0 & 0 & 0 & 0 \\
& 100 & 0 & 0 & 0 & 0 & 20 & 30 & 50 \\
& 200 & 0 & 0 & 0 & 0 & 25 & 40 & 70 \\
& 500 & 0 & 0 & 0 & 0 & 43 & 55 & 100 \\
& 1000 & 0 & 0 & 0 & 0 & 60 & 80 & 100 \\
\hline
\end{tabular}

The essential oil of E.camaldulensis induced $100 \%$ mortality in adults of $C$. maculatus, after 24 hours of exposure to the dose of $2 \mu \mathrm{l} / \mathrm{l}$ of air (Table 5). All the extracts of plants tested, except that of A. indica, caused $100 \%$ mortality, after $6 \mathrm{~h}$ of exposure to the highest dose $(20 \mu \mathrm{l} / 1$ of air). To obtain the same result with A. indica oil, the adult beetles should be exposed to a dose of $2000 \mu \mathrm{l} / \mathrm{l}$ air for 48 hours. In the control batches, the mortality was zero even after $96 \mathrm{~h}$.

Determination of $\mathrm{LD}_{50}$ and $\mathrm{LD}_{90}$ for essential oils of $C$. citratus, $C$. Nardus and $E$. camaldulensis tested by inhalation after 6 hours exposure:-

The graphs representing the regression lines made it possible to determine the $\mathrm{LD}_{50}$ and $\mathrm{LD}_{90}$ values of the essential oil and A. indica vegetable oil. The $\mathrm{LD}_{50}$ values are $6.41 \mu \mathrm{l} / \mathrm{l}$ of air for C. citratus, $7.24 \mu \mathrm{l} / 1$ of air for $C$. nardus, $3.54 \mu \mathrm{l} / \mathrm{l}$ air for E.camaldulensis and $778.537 \mu \mathrm{l} / 1$ Air for A. indica. Similarly, $\mathrm{LD}_{90}$ are $17.22 \mu \mathrm{l} / 1$ air for $C$. citratus, $17.55 \mu \mathrm{l} / \mathrm{l}$ of air for $C$. nardus, $16.43 \mu \mathrm{l} / \mathrm{l}$ air for E. camaldulensis and $1754,15 \mu \mathrm{l} / \mathrm{l}$ of air for A. indica. These results show that essential oil and $A$. indica vegetable oil are active on $C$. maculatus by inhalation, although those which have been more effective are those of E. camaldulensis with the lowest $\mathrm{LD}_{50}$ and $\mathrm{LD}_{90}$ of the order of $3.54 \mu \mathrm{l} / \mathrm{L}$ of air and $16.43 \mu \mathrm{l} / \mathrm{l}$ of air respectively. The correlation coefficients obtained are between 0.993 and 0.997 , which indicates a very strong correlation between the mortality and the dose of extract used. The set of results is indicated by the graphs in the figures below:

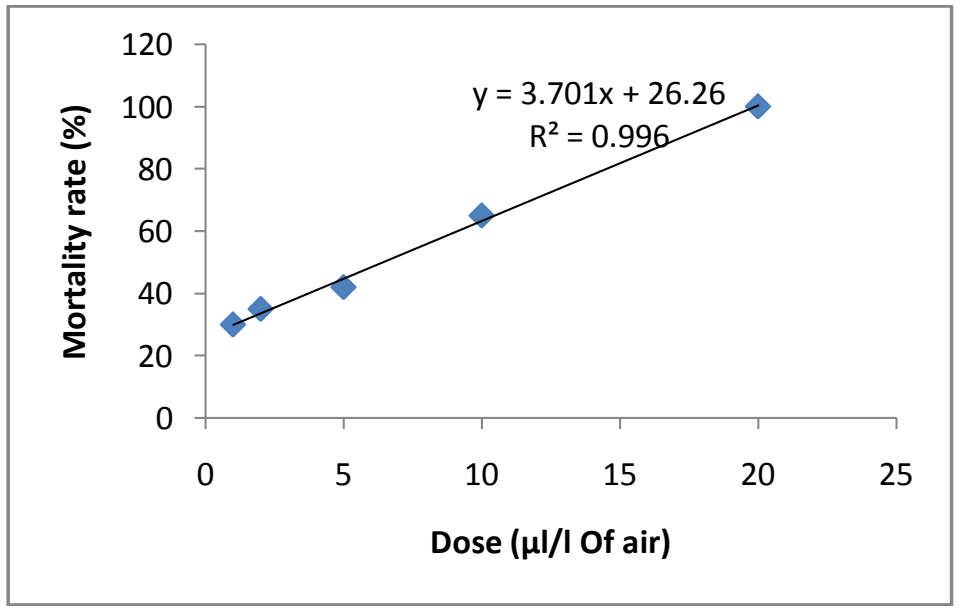

Figure 1:- Regression line of the mortality rate (inhalation treatment) of the essential oil of C. citratus 


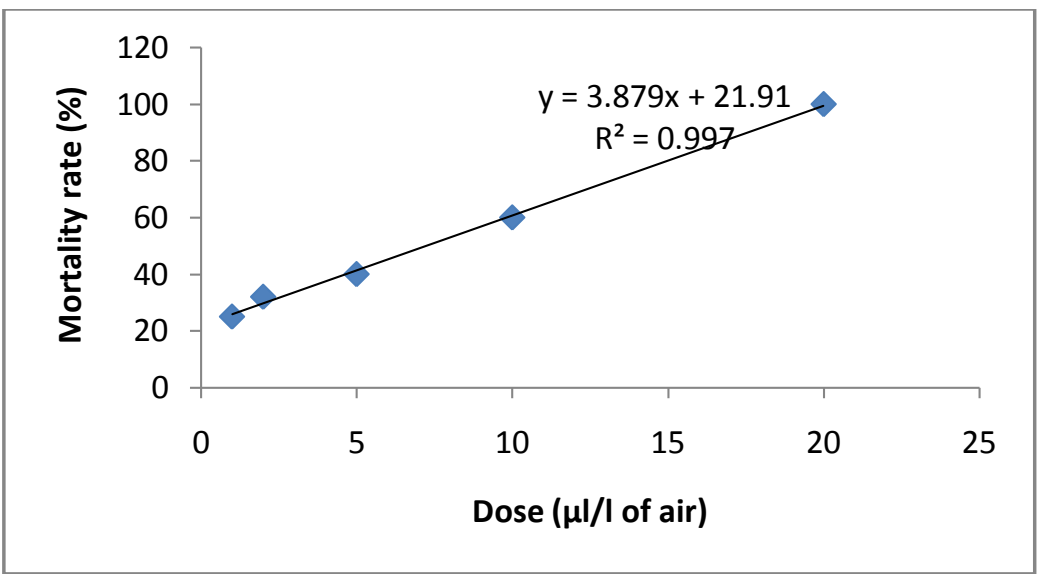

Figure 2:- Regression line of the mortality rate (inhalation treatment) of C. nardus essential oil

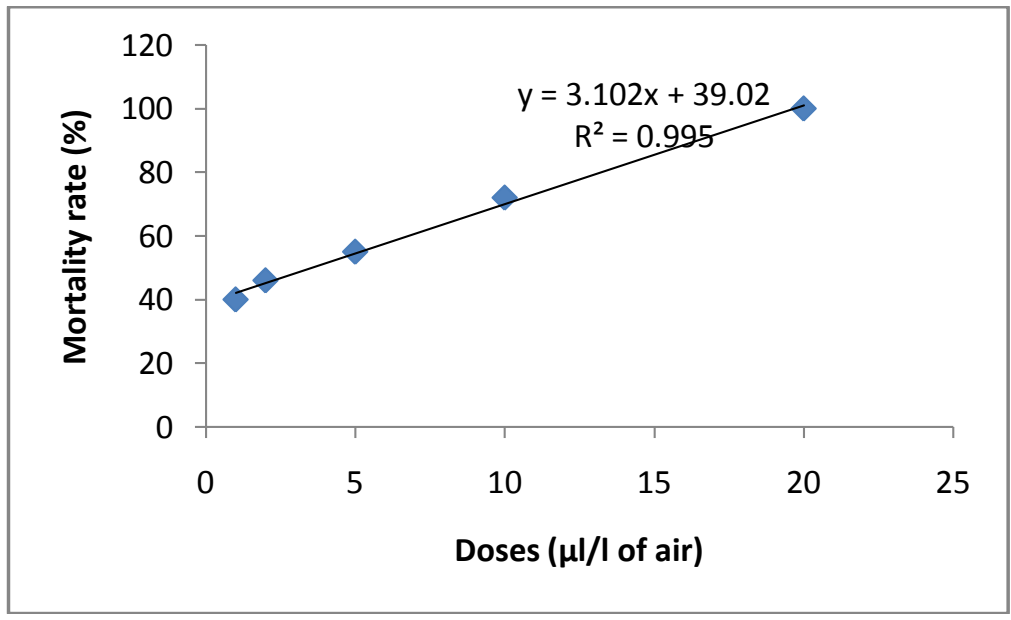

Figure 3:- Regression line of the mortality rate (treatment by inhalation) of E.camaldulensis essential oil.

Determination of $L D_{50}$ and $L D_{90}$ for $A$. indica oil tested by inhalation after 48 hours exposure.

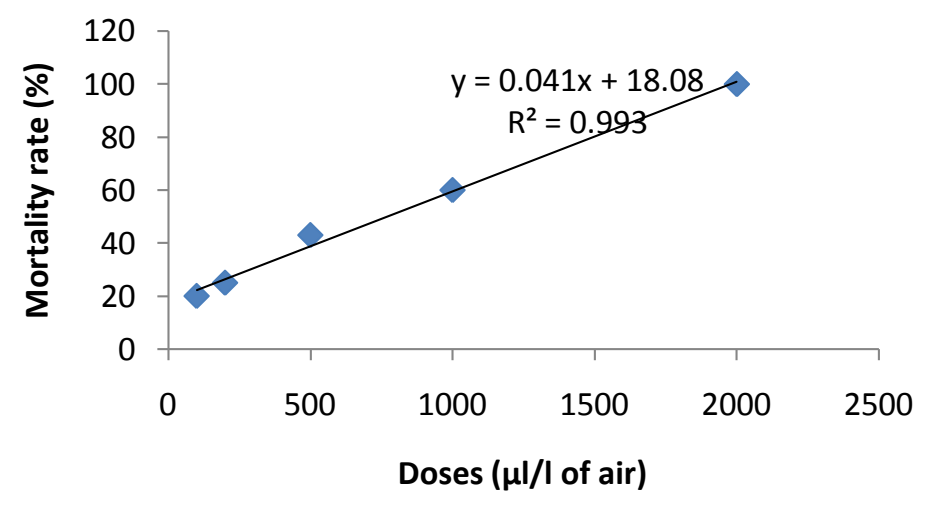

Figure 4:- Regression line of the mortality rate (treatment by inhalation) of $A$. indica oil

\section{Repulsive test:-}

Table 6:- Average rate of repulsivity(\%) (Mc Donald and al., 1970) of different plant extracts in relation to adults of C. maculatus (Means not sharing any letters are significantly different according to the test of Newman and Keuls at threshold $\mathrm{P}=5 \%)$.

\begin{tabular}{|c|l|l|l|c|}
\hline Dose $(\mu \mathrm{l})$ & C. citratus & C. nardus & E. camaldulensis & A. indica \\
\hline 1 & $41.33 \pm 3.21$ & $41.66 \pm 2.88$ & $71.66 \pm 1.52$ & $20.00 \pm 0.00$ \\
\hline
\end{tabular}




\begin{tabular}{|c|c|c|c|c|}
\hline & $(\mathrm{e})$ & $(\mathrm{e})$ & $(\mathrm{c})$ & $(\mathrm{g})$ \\
\hline 2 & $\begin{array}{c}46.67 \pm 5.77 \\
(\mathrm{e})\end{array}$ & $\begin{array}{c}62.33 \pm 2.51 \\
(\mathrm{~d})\end{array}$ & $\begin{array}{c}87.00 \pm 2.64 \\
(\mathrm{~b})\end{array}$ & $\begin{array}{c}21.00 \pm 1.00 \\
(\mathrm{~g})\end{array}$ \\
\hline 5 & $\begin{array}{c}80.67 \pm 1.15 \\
(\mathrm{~b})\end{array}$ & $\begin{array}{c}81.66 \pm 2.05 \\
(\mathrm{~b})\end{array}$ & $\begin{array}{c}100.00 \pm 0.00 \\
(\mathrm{a})\end{array}$ & $\begin{array}{c}21.66 \pm 2.88 \\
(\mathrm{~g})\end{array}$ \\
\hline 10 & $\begin{array}{c}87.33 \pm 6.42 \\
(\mathrm{~b})\end{array}$ & $\begin{array}{c}85.00 \pm 5.00 \\
(\mathrm{~b})\end{array}$ & $\begin{array}{c}100.00 \pm 0.00 \\
(\mathrm{a})\end{array}$ & $\begin{array}{c}35.00 \pm 5.00 \\
(\mathrm{f})\end{array}$ \\
\hline 20 & $\begin{array}{c}100.00 \pm 0.00 \\
(\mathrm{a})\end{array}$ & $\begin{array}{c}100.00 \pm 0.00 \\
(\mathrm{a})\end{array}$ & $\begin{array}{c}100.00 \pm 0.00 \\
(\mathrm{a})\end{array}$ & $\begin{array}{c}45.00 \pm 5.00 \\
(\mathrm{e})\end{array}$ \\
\hline $\begin{array}{l}\text { Average rate } \\
\begin{array}{l}\%) \text { of } \\
\text { repulsivity }\end{array}\end{array}$ & 71.19 & 74.13 & 91.73 & 28.53 \\
\hline $\begin{array}{l}\text { Repulsivity } \\
\text { class }\end{array}$ & Répulsive & Répulsive & Very Répulsive & $\begin{array}{l}\text { Low } \\
\text { Répulsive }\end{array}$ \\
\hline
\end{tabular}

The results of the analysis of variance for repulsivity tests show a significant difference for the essential oil and $A$. indica vegetable oil $(\mathrm{P}=0.000<0.05)$. All the essential oils showed an important activity towards the adults of $C$. maculatus. On the other hand, the A. indica oil showed a weak repulsive activity with respect to $C$. maculatus. E.camaldulensis was found to be the most repulsive with a $100 \%$ dose at the $5 \mu$ dose (Table 6).

\section{Discussion:-}

The present study revealed that the efficacy of essential oil and A. indica vegetable oil tested depends on their major constituents, regardless of the biological factor of $C$. maculatus considered. The essential oil and A. indica vegetable oil analyzed consist mainly of monoterpenes such as $\alpha$-pinene, $\beta$-pinene, camphene, limonene, $p$-cymene and terpinolene for some and $\alpha$-pinene, $\beta$-pinene, camphor and Eucalyptol for others. These compounds have often been characterized by their biocidal and repulsive activity against many stored insect pests (Keita and al., 2000, Ketoh and al., 2002, Kellouche and Soltani, 2004, Papachristos and Stamoupolos, 2002 and Kellouche and al ., 2010).

Moreover, the results obtained in our study reveal that all the essential oils and the vegetable oil tested are bioactive with cowpea beetle in contact treatments, affecting all the biological parameters of the Cowpea beetle.

The results we have achieved in contact treatments corroborate that of Mahfuz and Khalequzzaman (2007), which demonstrated a biocidal effect of five essential oils of cardamom, cinnamon, cloves, eucalyptus and $A$. indica on the biological activity of $C$. maculatus adults. Our results are in agreement with those reported by Kellouche and $a l$. (2010), which showed that, starting from the dose $10 \mu \mathrm{l} / 50 \mathrm{~g}$ of cowpea seeds, the essential oils of Eucalyptus globulus, Eucalyptus citriodora (Myrtaceae), Myrtus communis (Myrtaceae), Melaleuca vidiflora (Myrtaceae), Mentha piperita (Lamiaceae), Pogostemon cablin (Lamiaceae), Cupressus sempervirens (Cupressaceae), Salvia officinalis (Labiae), Cinnamomum zeylanicum (Lauraceae) and Citrus mendurensis (Rutaceae) have Significantly reduced the longevity of $C$. maculatus adults; This lifetime was reduced to less than 24 hours with the essential oils of cinnamon and Eucalyptus in the dose of $15 \mu \mathrm{l} / 50 \mathrm{~g}$, in the control batches, the adults live more than a week. The reduction in adult emergence recorded in our tests may be partly explained by the low egg hatching. It is likely that the vapors of essential oils diffuse through the chorion or respiratory siphon of the eggs and affect the physiological and biochemical processes associated with embryonic development (Raja and al., 2001). Similarly, Regnault-Roger and Hamraoui (1995) observed the effect of binalool, thymol and carvacrol on the fecundity of bean bean (Acanthoscelides obtectus).

The results obtained by inhalation clearly show that all essential oil and A. indica vegetable oil tested revealed a very highly significant effect on the mortality of $C$. maculatus adults as the dose and exposure time increased. Our results are in agreement with those reported by some authors who have demonstrated the efficacy of essential oil and A. indica vegetable oil (Reddy and Singh, 1998; Aiboud, 2012; Keïta and al., 2000; Taleb-Toudert, 2015). For example, the inhalation toxicity of C. citratus, C. nardus, E.camaldulensis essential oils and A. indica oil was evaluated against $24 \mathrm{~h}$ adults of $C$. maculatus; Different concentrations, ranging from $1 \mu \mathrm{l} / \mathrm{l}$ air to $2000 \mu \mathrm{l} / 1$ air, and different exposure times (6h-96 days) were tested. The results showed that mortality increases with increasing exposure time as well as with increasing concentration. At concentrations greater than $10 \mu \mathrm{l} / 1$ of air, the recorded mortality exceeds $50 \%$ after $6 \mathrm{~h}$, and reaches $100 \%$ after $12 \mathrm{~h}$ for the three essential oils tested. The analysis of mortality rates showed that E.camaldulensis $\left(\mathrm{LD}_{50}=3.540 \mu \mathrm{l} / \mathrm{l}\right.$ air and $\mathrm{LD}_{90}=16.435 \mu \mathrm{l} / \mathrm{l}$ air $)$ was more sensitive 
than $C$. citratus $\left(\mathrm{LD}_{50}=6.414 \mu \mathrm{l} / \mathrm{l}\right.$ of Air and $\mathrm{DL}_{90}=17,222 \mu \mathrm{l} / \mathrm{l}$ of air $)$ and $C$. nardus $\left(\mathrm{LD}_{50}=7,242 \mu \mathrm{l} / 1 \mathrm{of}\right.$ air and $\mathrm{LD}_{90}=17,553 \mu \mathrm{l} / \mathrm{l}$ of air). In contrast, at a concentration greater than $1000 \mu \mathrm{l} / \mathrm{l}$ of air, the recorded mortality exceeds $50 \%$ after $48 \mathrm{~h}$ and reaches $100 \%$ after $96 \mathrm{~h}$ for $A$. indica $\left(\mathrm{LD}_{50}=778.537 \mu \mathrm{l} / 1\right.$ of air and $\mathrm{LD}_{90}=1754,146$ $\mu \mathrm{l} / \mathrm{l}$ of air). These results show that E. camaldulensis, $C$. citratus and $C$. nardus essential oils could be applicable to the management of cowpea insect populations. Lemongrass, clove and lemon essential oils have also been found to be significantly toxic to $C$. maculatus and are ranked according to the following increasing order of toxicity: lemon, lemongrass, clove; However, significant mortalities occur as soon as there is direct contact with an oil, whereas inhalation tests appear to be less effective (Lale, 1991).

These natural substances caused the death of the beetle, after a $96 \mathrm{~h}$ exposure to the dose $16 \mu \mathrm{l}$. A knock down effect was observed with essential oils of E. globulus, E. radiata, L. nobilis, O. basilicum, M. spicata and A. triphylla, demonstrating the effectiveness of these natural substances by Fumigation, which would be the consequence of their richness of monoterpene compounds. This shock effect resulted in the instant immobility of the adult bruches from their contact with the vapors of these oils in the hermetic jars at the dose $16 \mu \mathrm{l} / 1$ of air after $24 \mathrm{~h}$ of exposure. Nyamador (2001) reported the increase in acetylcholinesterase in individuals of $C$. subinnotatus, in a Knock down or death situation, which is related to the release of acetylcholine, a neuromediator, induced by activity of the essential oil of Cymbopogon giganteus. This important release of acetylcholine neuro mediator would, according to Badiou and al. (2008), the origin of an activity producing AchE in the cholinergic system of the bee in order to restore AchE / Ach.

The results obtained in Table 6 show a dose effect for the essential oil and $A$. indica vegetable oil tested. The $E$. camaldulensis, $C$. citratus and $C$. nardus essential oils showed a very repulsive activity compared to $A$. indica oil. Our results are similar to those of Taleb-Toudert (2015) who tested 10 essential oils and caused $100 \%$ mortality to adults of $C$. maculates at a dose of $16 \mu \mathrm{l}$. Agarwal and al. (2001) demonstrated the toxicity and repellency of 1.8 cineoles against $C$. maculatus, Rhyzopertha dominica (Coleoptera: Bostrychidae) and Sarocladium oryzae. This chemotype was repulsive with a repulsivity rate of $65 \%$ to $74 \%$, with respect to these three insect pests, at the dose 4 $\mu \mathrm{l} / \mathrm{ml}$ after 1 hour of exposure. After 2 hours of exposure, the different doses of the essential oil of the leaves of Callistemon viminalis (from 0.031 to $0.251 \mu \mathrm{l} / \mathrm{cm} 2$ ) caused a repulsion with a rate ranging from 36.6 to $80 \%$ With respect to adults of Acanthoscelides obtectus (Coleoptera: Bruchidae). This clearly shows that the percentage of repulsion increases with dose (Ndomo and al., 2008). Other authors have repulsed many other essential oils, such as Cinnamomum zeylanicum and Eucalyptus citriodora, which have proven to be very repulsive, with $90 \%$ and $86.6 \%$ (Class IV) levels, respectively. S. officinalis, M. pipereta, C. mendurensis and M. vidiflora were repulsive to $C$. maculatus. The essential oils of Eucalyptus globulus, Myrtus communis, Pogostemon cablin and Cupressus sempervirens were moderately repulsive (Class III) (Kelouche and al., 2010).

\section{Conclusion:-}

Our study is based on the search for alternative solutions that reduce the post-harvest losses caused by insect pests, such as cowpea beetle by using plant extracts to limit pesticide disadvantages.

In view of the results obtained, we can conclude that the essential oil and $A$. indica vegetable oil tested have a good biological activity with respect to the cowpea beetle $C$. maculatus. In the set of contact tests E.camaldulensis, $C$. citratus and $C$. nardus appear to be most effective in the control of $C$. maculatus. A. indica is the least effective oil in contact testing. In the inhalation tests, we found that all the extracts tested revealed a significant insecticidal effect on the lifetime of adults of $C$. maculatus, except $A$. indica, which had a low effect with the highest dose (20 $\mu \mathrm{l} / 1)$ And the longest treatment time (96h). Repulsivity tests show that E.camaldulensis, $C$. citratus and $C$. nardus have a more marked activity compared to A. indica.

The results obtained show that the essential oil and $A$. indica vegetable oil used have a good insecticidal action with regard to cowpea beetle, their toxicity varies according to the type of test carried out (contact, inhalation or repulsiveness); it is therefore very interesting to continue this work by highlighting the synergistic action of these extracts in the fight against the cowpea beetle in storage.

\section{References:-}

1. Abbott W.S., (1925) : A method of computing the effectiveness of an insecticide. J. Econ. Entomol., 18 : 265267. 
2. Agarwal M., Walia S., Dhingra S. and Khambaj B. P. S., (2001) : Insect growth inhibition, antifeedant and antifungal activity against Spilosoma oblique and Rhizoctonia solani. Pest Manag. Sci., vol 57: 289-300.

3. Badiou A., Meled M. and Belzunces L.P., (2008) : Honeybee Apis mellifera acetylcholine stérase. A biomarker to detect deltamethrin exposure. Ecotoxicology and Environmental Safety, in press., Vol. 69: 246253.

4. Bottenberg H., Tamo M., Arodokoun D., Jakai L. E. N., Singh B. B., Youm O., (1997) : Population dynamics and migration of cowpea pests in northern Nigeria: implication for integrated pest management : 27 1-284. In: Advances in Cowpea Research, edited by. Singh B. B., Mohan Raj D. R., Dashiell K. E. \&. Jackai L. E.N. Copublication of IITA, Ibadan, Nigeria

5. Delobel A., Tran M., (1993) : Les coléoptères des denrées alimentaires entreposées dans les régions chaudes. ORSTOM/CTA. Faune tropicale 32. Paris. 424p.

6. Giga D. P., Smith R.H., (1983) : Comparative life history studies of four Callosobruchus species infesting cowpea with special reference of Callosobruchus rhodesianus Pic (Coleoptera: Bruchidae). J. stored prod. Res. 19: pp. 189- 198.

7. Hernandez Ochoa L. R., (2005) : Substitution de solvants actives de synthèse par un combine «Solvant (Actif) d'origine végétale». Thèse de doctorat en sciences des agroagresseurs. Institut National Polytechnique de Toulouse. 224p.

8. Keïta M.S., Vincent Charles., Schmit J. P., Rammaswany S., Belanger A., (2000) : Effect of various essential oils on Callosobruchus maculatus (F.) (Coleoptera: Bruchidae). Journal of stored products Research. 36: pp. 355-364.

9. Kellouche A., Soltani N., (2004) : Activité biologique des poudres de cinq plantes et de l'huile essentielle d'une d'entre elles sur Callosobruchus maculatus (F.). International Journal of Tropical Insect Science, 24 (1): 184191.

10. Kellouche A., Ait Aider F., Labdaoui K., Moula D., Hamadi N., Ouramdam A., Frerot B., Mellouk M., (2010) : Biological activity of ten essential oil against Cowpea beetle Callossobruchus maculatus Fabricius (ColeopteraBruchidea). International Journal of Integrative Biology, Vol. 10:86-89.

11. Ketoh, G.K, Glitho, AI., Huignard, 1. (2002) : «Susceptibility of the Bruchid Callosobruchus maculatus (Coleoptera:Bruchidae) and its Parasitoid Dinarmus basalis (Hymenoptera: Pteromalidae) to three Essential oils». J Econ. Entomol.,95: 174182.

12. Lale N. E. S., (1991) : The biological effects of three essential oils on Callosobruchus maculates (F) (Coleoptera: Bruchidae). J. African Zool., vol 105: 357-362.

13. Mahful I., Khalequzzaman M., (2007) : Contact and Fumigant Toxicity of Essential Oils against Callosobruchus maculatus. University Journal of Zoology, Rajshahi university, vol 26: 63-66.

14. Ndomo A., Ngamo L., Topondjou L., Tchouanguep F., Hance T., (2008) : Insecticidal effects of the powdery formulation based on clay and essential oil from leaves of clausena anisata (Willd) J. D. ex Benth (Rutaceae) against Acanthoscelides obtectus (Say) Hook.

15. Nyamador S.W., (2001) : Capacités reproductrices de la souche Togolaise de Callosobruchus maculatus F. (Coleoptera : Bruchidae). Journal Research University. Lomé (Togo) vol 5 : 361-366.

16. Papachristos D.P., Stamopoulos D.C., (2002) : Reppellent, toxic and reproduction inhibitory effects of essential oil vapours an Acanthoscelides obtects (Say) (Coleoptera: Bruchidae Journal of Stored Products Research. Vol 38: 117-12)

17. Rahman S., Ibrahim U., Ajayi F., (2008) : Effect of defoliation at different growth stages on yield and profitability of cowpea (Vigna unguiculata (L.) Walp.). EJEAFCche, 7(9): 3248-3254.

18. Raja N., Albert S., Ignacimuthu S., Dorn S., (2001) : Effect of volatile oils in protecting stored cowpea Vigna unguiculata (L.) Walpers against Callosobruchus maculates (F.) (Coleoptera: Bruchidae) infestation. Journal of Stored Products Research. Vol 37: 127-132.

19. Reddy A. V., Singh R. P., (1998) : Fumigant toxicity of neem (Azadirachta indica A. Juss.) see oil volatiles against pulsa beetle, Callosobruchus maculatus Fab. (Col., Bruchidae), J Appl. Ent, vol122 : 607-611.

20. Regnault-Roger C., Hamraoui A., (1995) : Efficiency of plants from South of France used as traditional protectants of Phaseolus vulgaris L. Journal of Stored Products Research, 29, 3, 259-264.

21. Taleb-Toudert Karima, (2015) : Extraction et caractérisation des huiles essentielles de dix plantes aromatiques provenant de la région de Kabylie (Nord Algérie). Evaluation de leurs effets sur la bruche du niébé Callossobruchus maculatus (Coleoptera: Bruchidae). Thèse de doctorat en Sciences Biologiques. Université MOULOUD MAMMERT de Tizi-Ouzou, Faculté des Sciences Biologiques et des Sciences Agronomiques du Département de Biologie Animale et Végétale ; 206p. 